H. E. COOMANS

\title{
VOLKSNAMEN VOOR WEEKDIEREN OP DE NEDERLANDSE ANTILLEN
}

Uit de aanwezigheid van veel Indiaanse schelpenhopen die op alle eilanden van de Nederlandse Antillen voorkomen, kunnen wij afleiden dat de weekdieren een belangrijke rol speelden in het leven van de oorspronkelijke bewoners dezer eilanden. Veel soorten worden erin aangetroffen (VAN HEEKEREN, I963, p. 6, II), en het is gebleken dat de dieren niet alleen van belang waren als voedsel, de schelpen werden bovendien gebruikt ter vervaardiging van werktuigen en sieraden.

De huidige bewoners van de Nederlandse Antillen hebben slechts weinig belangstelling voor de weekdieren, ook mollusken of schelpdieren genoemd. Van de vele honderden soorten mollusken die op en om deze eilanden gevonden worden, heeft slechts een gering aantal een volksnaam gekregen: op de Benedenwindse eilanden (Aruba, Curaçao en Bonaire) in het Papiamento, op de Bovenwindse eilanden (St. Maarten, Saba en St. Eustatius) in het Engels.

De auteurs die de weekdierfauna van deze eilanden behandelen, vermelden in de regel niet de volksnamen. Ten dele wordt dit veroorzaakt door het feit dat deze auteurs de namen niet kennen, omdat zij niet op de Antillen geweest zijn of waren (VERNHOUT, I9I4; Schepman, I9I5; van Benthem Jutting, I925, I927; Adam, I937; Coomans, I958), of men was wel op de eilanden geweest, maar aan de volksnamen werd geen aandacht besteed (BAKER, I924; CoOMANS, I963b, I967).

Aangezien van de Antilliaanse planten (ARNOLDO, I954) en van enkele diergroepen, zoals de zoogdieren (Husson, I960), vogels (Voous, I955), reptielen (WAGENAAR HuMmELINCK, I940), vissen (Boeke, I907, p. 47-53; MetZelaAR, I9I9, p. I75-I79; ZANEVELD, I959) wel bekend is welke locale namen aan de diverse soorten gegeven zijn, leek het de schrijver nuttig een onderzoek te wijden aan de locale weekdiernamen. Deze publicatie is daarvan het resultaat. 
De schrijver is dank verschuldigd aan frater M. Arnoldo Broeders, pater P. Brenneker O.P., drs. I. J. Hermans en dr. P. WagenaAr HuMMELINCK. Hij houdt zich aanbevolen voor alle nadere inlichtingen met betrekking tot het in dit artikel behandelde onderwerp. De foto's werden gemaakt door L. R. HAFKamP op het Zoölogisch Museum te Amsterdam.

\section{LOCALE NAMEN OP CURAÇAO, ARUBA EN BONAIRE}

Voor de A.B.C.-eilanden is Paddenberg (I8I9, p. 4I-45) de eerste auteur die aandacht heeft besteed aan de locale schelpen. Hij spreekt van porceleintjes en venus-schelpen, en noemt als eetbare soorten de oester, cocqueluizen, alikruik, en de Spaansche zeekat of sepia.

TEenstra (1836, p. 288-289) vermeldt de ammonshoren, Spaansche zeekat of zeepia, paloulie, alikruik, coqueluis en oester. Verder nog de zonne-, muzijk-, kakkerlak- en porcelein-schulpen. Laatstgenoemden kunnen echter niet tot de volksnamen van de Nederlandse Antillen gerekend worden. Het zijn algemene benamingen die destijds in Nederland gebruikt werden voor bepaalde schelpenfamilies. TEENSTRA besluit dat er nog "eene legio van andere" schelpdieren is, "voor welke ik geen' naam weet; vooral Bonaire munt in veelheid en schoonheid van schulpen uit".

Minder prozaïsch is Simons (I868, p. I50-I5I) die alle aan hem bekende planten- en diersoorten van Curaçao opsomt, zowel met wetenschappelijke als met locale namen, voor zover bestaand tenminste. Weekdieren met een volksnaam die Simons noemt zijn: oester, paloeli, patoeti di vera, tapa conchi, kokolisji di kalkoena koorkoor, en zeekat. Over de mollusken van Simons' faunalijst werd reeds eerder door ons gepubliceerd (Coomans, I964).

BoEke (I907, p. I43) geeft in zijn visserijrapport als locale schelpennamen: mangrove-oester, paloeli, tapacontsjie, en kokoliesjie di kalakoena. WAGENAAR HUMMELINCK (I940, p. 89, I02) noemt cocolishi cabritu, of kokoliesjie kabritoe, cocolishi di carné en kokoliesjie die kalakoena. Coomans (I959) vermeldt tapa conchi (p. 6), kokoliesjie di kalakoena en karko (p. II), karko duru (p. I3) en kiwa (p. I4). Bij DE JONG \& KRISTENSEN (I965) tenslotte zijn kiwa (p. I4) en carco (p. 25) genoemd.

$\mathrm{Al}$ deze auteurs geven slechts enkele namen, maar zij vermelden steeds welke diersoorten met deze namen bedoeld worden. Juist andersom is het bij BRENNEKER, die meestal publiceert onder het pseudoniem Paul (of Frans) van Venlo. Hij noemt veel Papia- 
mentse weekdiernamen, maar ze zijn soms verscholen tussen allerlei visnamen, en dus moeilijk te vinden, terwijl hij slechts in enkele gevallen aangeeft welke soort aan de locale naam beantwoordt. In BRENNEKER's publicaties (I946, I947, I950, I953, I954, I959, I96I) treffen wij aan: carco, carco duru, carco indjan, cocolishi, cocolishi carne, cocolishi hustu, cocolishi indjan, cocolishi masbangu, cocolishi rondo, djacarao, hustu en hoestoe, kincon en kinkon, kiwa, tapa conchi, zeekat, zeekat bulado(r), zeekat cora, zeekat di piedra, zeekat pia largu, zeekat tumado, zilverschelp. Ons contact met pater BRENNEKER heeft ertoe bijgedragen dat de meeste van deze locale namen in wetenschappelijke namen konden worden vertaald.

In drie Papiamentse woordenboeken vonden wij slechts enkele schelpennamen: cokelisje, kokelisji, oester (Anoniem, 1875); cleconchi, cocolishi, oester, paluli, soldachi, tapa concha, zeekat (JANSEN, I945, I947).

\section{LIJST VAN SCHELPENNAMEN VAN DE BENEDENWINDEN}

De ons bekende molluskennamen die op Curaçao, Aruba en Bonaire gebruikt worden of werden zijn hieronder in alfabetische volgorde behandeld. De diverse spellingswijzen alsmede de oorsprong en afleiding van de namen worden aan het eind van de naamlijst besproken. Op de Papiamentse namen zijn klemtoontekens gezet, ook in gevallen waar deze in de regel niet worden aangebracht.

\section{Alikruik [Fig. 7] Cittarium pica (Linnaeus)}

Dit is de Nederlandse naam voor Littorina littorea (Linnaeus), een soort die niet op de Antillen voorkomt. PADDENBERG (I8I9, p. 44) noemt de alikruik van Curaçao, en hij zegt erbij dat ze gegeten wordt. Teenstra (1836, p. 289) herhaalt deze uitspraak en vult nog aan dat de alikruik op Curaçao 'coqueluizen' (zie aldaar) genoemd wordt. Wij menen (Coomans, I959, p. I4) dat deze Curaçaose alikruik de soort Cittarium (= Livona) pica is, die tegenwoordig 'kiwa' (zie aldaar) heet. Het is namelijk een algemeen voorkomende soort, die ook nu nog wordt gegeten, en die in dezelfde omstandigheden leeft als de Nederlandse (eveneens eetbare) alikruiken en de Curaçaose (niet-eetbare) krékchi's: op een rotsachtige ondergrond. 
VOLKSNAMEN VOOR WEEKDIEREN OP NED. ANTILLEN I6I

Ammonshoren [Fig. 6] Spirula spirula (Linnaeus)

Deze naam komt alleen voor bij Teenstra (I836, p. 288) die haar als volgt beschrijft: "Onder de schulpen is de fraaije witte Ammonshoren zeer schoon, zijnde wit en geringd met een' parel d'amourglans". Zeer duidelijk herkennen we hieruit het kleine inktvisje Spirula, waarvan de schelpjes veel aanspoelen op de noordkust van de Benedenwindse Eilanden. Indien de naam ammonshoren gebruikelijk was op Curaçao, dan kunnen we haar tot de verdwenen volksnamen rekenen, want tegenwoordig wordt deze naam niet meer vernomen.

\section{Cacaláca di áwa [Fig. I5] Acanthopleura granulata (Gmelin) Chiton soorten}

Kakkerlakken komen veel voor op de Nederlandse Antillen, en naar analogie van deze landinsecten heeft men een 'gelijkend' dier de waterkakkerlak genoemd. Deze naam, die nergens in de literatuur voorkomt, werd ons meegedeeld door de Curaçaose bioloog dr. I. J. HeRmans, die er een dubbele betekenis voor wist. Tijdens excursies in zijn schooljaren werd de naam cacalaca di awa gegeven aan de keverslakken, waarvan er diverse soorten voorkomen op Curaçao. (Vergelijk cacalaca di awa en keverslak, kakkerlak en kever zijn beide insecten!). Tapa conchi is een meer gebruikelijke volksnaam voor de keverslakken. Tegenwoordig noemen de vissers op Curaçao bepaalde zeekreeftjes ook cacalaca di awa.

\section{Carcó [Fig. 3] Strombus gigas Linnaeus}

De carco of karko is ongetwijfeld de meest bekende zeeslak van West-Indië, opvallend door zijn grootte en zijn fraaie kleuren, en algemeen voorkomend rondom de Nederlandse Antillen. Het dier wordt commercieel gevist in Lac op Bonaire. BoEKE (1907) vermeldt deze soort niet in zijn visserijrapport, waaruit we mogen afleiden dat de vangst op deze weekdieren eerst later in deze eeuw begonnen is. Opmerkelijk is ook dat de naam carco ons niet bekend is uit de Antilliaanse literatuur van de vorige eeuw, tenzij het 'koorkoor' bij Simons (I868, p. I5I) een drukfout is voor karko. Te oordelen naar de grote hopen van lege schelpen aan de Cai-zijde van Lac is er jaren intensief naar dit schelpdier gevist. 
Wellicht te intensief omdat het aantal volwassen dieren aanzienlijk verminderd is in de laatste jaren (KRISTENSEN, I963, p. 3; DE Jong \& KRISTENSEN, I965, p. 26). Over de economische waarde van dit dier werd reeds eerder door ons gerapporteerd (CooMANS, I959, p. II-I2, 43-44, 46, 50). Het is de enige slak die ook de belangstelling heeft van de sportvissers (BRENNEKER, I946, p. 4I-43; I950, p. 57; I953, p. 39-4I; HAKKENBERG VAN GAASBEEK, I955, p. I04-II6), meestal met de bedoeling om van de schelp een schemerlamp te maken. WagenaAR Hummelinck \& Roos (I969, p. I, 9; fig. I4, 28, 35, 36, 42) hebben bij hun onderzoek van het Lac aan het voorkomen van Strombus gigas bijzondere aandacht geschonken. Zij nemen aan dat het merendeel van de tien, tot $3 \frac{1}{2}$ meter hoge schelphopen welke de toeristische attractie vormen van Cai, reeds dateren uit de eerste helft van de ca. zestig jaren dat de carco-visserij hier 'in het groot' werd uitgeoefend door leden van de families EngelHaRd en Soleano. Ook voor de Caquetíos, de Indianenstam die onze Benedenwindse eilanden eens bewoonde, was de carco een belangrijke schelp. In bijna elke indianenschelphoop treffen we de schelpresten van deze soort aan. J. E. RANDALl (I964) wijdde een uitvoerige studie aan de biologie van dit weekdier. Er is zelfs sprake van deze soort in de medische literatuur (ANONIEM, I96I, p. 7) in verband met de kinderverlamming.

Beperkt het eten van de carco op de Nederlandse Antillen zich tot de gespierde voet, de vissers op de Bahamas hebben meer belangstelling voor de penis van deze dieren, het eten hiervan zou hen sexuele potentie geven (Coomans, I962, p. I028). Een soortgelijke mening waren onze voorouders toegedaan, het eten van schelpdieren veroorzaakte "lust om by te slapen, 't welck de lustige en delicate luyden wel aenstaet" (DE WAAL, z.j., p. IOII02). Behalve als voedsel en voor schemerlamp dient de carco ook als versiering van tuinen, als deurklem, en als hoorn om mededelingen te doen, bij voorbeeld het overlijden van iemand. Een Curaçoase legende waarin de carco de hoofdrol speelt, wordt verteld door BRENNEKER (I96I, p. 3I-32, no. II4). 'Kincon' (zie aldaar) is een andere volksnaam voor de carco.

\section{Carcó dúru \\ [Fig. 4] \\ Strombus costatus Gmelin}

Dit is een naaste verwant van de voorgaande soort, maar veel minder algemeen dan de carco, vrij zeldzaam zelfs, zodat het ons verbaast dat deze soort een volksnaam gekregen heeft. De schelp 
VOLKSNAMEN VOOR WEEKDIEREN OP NED. ANTILLEN I63

is kleiner $(\mathrm{I} 5 \mathrm{~cm})$ dan die van de carco $(25 \mathrm{~cm})$, niet rose gekleurd en met een verdikte buitenlip. Het is een stevige schelp, zodat het achtervoegsel 'duru' (= hard) wèl gekozen is. BRENNEKER (I953, p. 40, 97) noemt deze soort 'zilverschelp', naar de zilverkleurige buitenlip, maar de Latijnse naam (Strombus raninus) is fout. Zijn figuur (BRENNEKER, I950, p. 57) toont ons duidelijk welke soort bedoeld wordt met carco duru. Dezelfde auteur (BRENNEKER, I946, p. 42) deelt mede dat deze soort door de vissers voor giftig wordt gehouden. Het is mogelijk dat de carco duru vroeger algemener voorkwam op de Benedenwinden, want ze wordt méér aangetroffen in de Indiaanse schelphopen. Op veel Westindische eilanden werd de stevige buitenlip door de Indianen benut als bijl (van Heekeren, I963, pl. 8; Coomans, I965, p. 20, fig. 5).

\section{Carcó indján [Fig. I] Cassis tuberosa (Linnaeus) Melongena melongena (Linnaeus)}

Pater Brenneker beschreef ons deze schelp als "groot en driehoekig, bruin gevlekt, hier zeldzaam". De soort is ook genoemd in een van zijn publicaties (BRENNEKER, I946, p. 43). Uit zijn beschrijving kunnen we afleiden dat het Cassis tuberosa is. Het is merkwaardig dat deze zeldzame soort een Papiamentse naam heeft, terwijl veel algemene soorten naamloos bleven. Het is niet duidelijk waarom deze schelp het achtervoegsel 'indjan' (Indiaan) gekregen heeft. Ook in indiaanse schelphopen is ze zeldzaam. WAGENAAR HUMMELINCK alsmede de auteur zijn van mening dat met carco indjan een andere weekdiersoort wordt bedoeld: Melongena melongena (Linnaeus), waarvan de grote, opvallende schelp wèl in vele indiaanse afvalhopen wordt gevonden.

\section{Glecónchi}

[Fig. 5]

Volgens JANSEN ( 1945, p. 40) is dit woord alleen op Aruba in gebruik, het heeft dezelfde betekenis als 'tapa concha' (zie aldaar), voor welk woord hij de vertaling zeepokken geeft. Waarschijnlijk vallen onder deze 'zeepokken' eveneens de hoedjesslakken, die in hetzelfde gebied als de echte zeepokken (Balanus) leven, er een uitwendige gelijkenis mee vertonen, en dezelfde leefwijze hebben, vastgehecht aan de rotsen. Danken zij aan deze leefwijze misschien de naam cle(= kleef?)-conchi? 


\section{Cocolíshi}

Dit is een verzamelnaam, waarmee men de schelpen of schelpdieren in het algemeen aanduidt. Het wordt ook gespeld als kokoli(e)sji(e). Het woord cocolishi is een verbastering van co(c)queluizen (zie aldaar). Wij lezen dit woord voor het eerst bij Simons (I868, p. I50) 'Kokolisji di kalkoena'. In het anonieme Nederlandsch-Papiamentsch-Spaansch woordenboekje, verschenen te Curaçao in I875, vinden we de volgende vertalingen: schelp cokelisje - concha (p. 89), en zeehoorn - kokelisji - caracol, concha (p. I3o). Men lette op de beide spelwijzen van hetzelfde Papiamentse woord.

Aangezien cocolishi 'schelpen' betekent, worden de diverse soorten van schelpen aangeduid door een tweede naam. Deze worden hierna besproken.

In de volksgeneeskunst spelen cocolishi een rol, het eten ervan is een oud huismiddel tegen asthma (BRENNEKER, I96I, p. I2, no. 3I).

Cocolíshi (di) cabrítu [Fig. I4] Tudora megacheilos (Potiez $\&$ Michaud)

Dit is een van de beide landslakken met een volksnaam. Deze soort wordt alleen op Curaçao en Aruba gevonden, maar de naam cocolishi cabritu schijnt beperkt tot Curaçao (WAGEnaAR HumMELINCK, I940, p. 89). Deze soort is zeer algemeen maar komt in minder groot aantal voor dan de cocolishi di kalakoena (zie aldaar). 'Cabritu' betekent geit, maar waarom deze soort genoemd is naar de geit, overigens het meest opvallende zoogdier van Curaçao, is ons niet bekend. Wellicht om de kleur van het slakkenhuis (cf. cocolishi carne).

BAKER (I924, p. 6I) die de landslakken van Curaçao, Aruba en Bonaire uitvoerig bestudeerde, onderscheidde verschillende ondersoorten van Tudora megacheilos, een daarvan is genoemd 'kabrietensis'. Deze wetenschappelijke naam werd echter niet gegeven om de volksnaam, maar naar de plaats waar deze ondersoort gevonden wordt, de Kabrietenberg op Curaçao.

Cocolíshi (di) carné [Fig. I3] Cerion uva (Linnaeus)

Dit is een andere naam voor het landslakje dat ook cocolishi di 
VOLKSNAMEN VOOR WEEKDIEREN OP NED. ANTILLEN I65

kalakoena (zie aldaar) wordt genoemd. Carne $=$ schaap, wellicht duidt dit op de witte kleur van de schelp.

\section{Cocolíshi hústu [Fig. I6] Pinna carnea Gmelin}

Hustu is een verbastering van oester, maar in verbinding met cocolishi wordt een geheel andere schelp bedoeld, de steekmossel, zo werd ons meegedeeld door pater P. BRENNEKER. Pinna carnea is een soort die algemeen voorkomt rondom de Benedenwindse eilanden, de punt van de schelp steekt in het zand, het brede gedeelte komt erboven uit (Kristensen, I963, fig. op p. 4). De steekmossel is het grootste tweekleppige weekdier van WestIndië, zij kan een lengte bereiken van $25 \mathrm{~cm}$. In de soorten van het geslacht Pinna kunnen parels ontstaan (Coomans, I959, p. $44 a)$.

\section{Cocolíshi indján [Fig. 8] Conus soort(en)}

Er worden een tiental soorten van kegelslakken (Conus) op de Nederlandse Antillen gevonden (Coomans, I958, p. 99-Ioo, pl. I4-I5; I963a, p. 9-IO; DE JoNG \& KRISTENSEN, I965, p. 44-46). Het is ons niet bekend of een dan wel meer soorten als cocolishi indjan worden aangeduid. Twee vrij grote en algemene soorten komen het meest in aanmerking: Conus regius Gmelin en Conus ranunculus Hwass. Aangezien de kegelslakken zeer fraai gekleurd zijn, werden ze door de vroegere Indianen van de Nederlandse Antillen wel gebruikt als versiering. Zo vond de schrijver op Curaçao een exemplaar van de rood gekleurde Conus granulatus $\mathrm{L}$. die als hanger gediend had. Overigens is niet duidelijk waarom Conus naar de Indianen genoemd is.

\section{Cocolíshi di kalakóena [Fig. I3] Cerion uva (Linnaeus)}

Een andere naam voor deze soort is cocolishi carne. Dit is het meest opvallende landslakje van de ABC-eilanden, en het wordt alleen hier en nergens anders ter wereld gevonden. Eens werden de slakkenhuisjes gebruikt als kalkhoudend voedsel voor kalkoenen, waardoor de naam verklaard is. BoEkE (I907, p. I43) vermeldt zelfs de uitvoer van deze slakken naar Duitsland, per kilo slakjes werd één cent betaald. BRENNEKER (I96I, p. I03, no. 423) noemt een medisch gebruik van deze soort: fijngestampt en met azijn vermengd bij zieken op de voetzool gesmeerd, verdrijft 
het de koorts! De volksnaam is volgens WagenaAR HUMmelinck (I940, p. I02) alleen op Curaçao in gebruik.

Dat dit opvallende landslakje reeds veel eerder in de belangstelling van de bewoners van deze eilanden stond bewijst het aanwezig zijn van Cerion uva in praehistorische afvalhopen bij het Meer van Valencia, in Venezuela. Verrassend was ook het voorkomen van talrijke exemplaren in een aardlaagje met vuurresten op een plaats waar bij Hato skeletten van Indianen werden gevonden (WAGENAAR HUMMELINCK, I940, p. I02; I959, p. 85). HUMMELINCK vond op enkele plaatsen hopen Cerions waarvan bij alle exemplaren het topje van de schelp ontbrak; hij meent hieruit te mogen afleiden dat ook Cerion deel uitmaakte van het menu van de Indiaanse bewoners van Curaçao.

\section{Cocolíshi masbángu}

Het is ons niet bekend welke soort met deze naam wordt aangeduid, ook pater BRENNEKER (I947), aan wie deze naam is ontleend, kon ons hierover niet nader inlichten. Ongetwijfeld is het een zeeschelp, want de naam vernam hij van de vissers van St. Michiels Baai. De masbangu, een verbastering van marsbanker, is een zeevis, Selar crumenophthalmus (Bloch).

\section{Cocolíshi rondó}

Ook voor deze naam is niet bekend welke schelpensoort ermee bedoeld wordt, en het achtervoegsel 'rondo' (= rond) is weinig verhelderend. Om dezelfde reden als bij de cocolishi masbangu nemen we aan dat het een mariene soort is.

\section{Co(c)queluis}

Bij Paddenberg (I8I9, p. 44) kunnen wij lezen, in zijn beschrijving van Curaçao: "Van de schulpdieren, hoe menigvuldig in getal, eet men slechts de oesters en een kleine mossel, hier Cocqueluizen genaamd, en ook de Alikruik".

TeEnstra ( 1836 , p. 289 ) heeft een iets andere mening: "de weinige hier gevondene mosselen, Paloulie en de Alikruik (welke laatste mede een schulpdier is) zijn van weinig waarde; echter worden laatstgemelde schulpdieren (die op Curaçao Coqueluizen genoemd worden) door velen met smaak gegeten". Is bij de eerste een mossel $=$ cocqueluis, bij de laatste is mossel $=$ paloulie, en 
alikruik $=$ coqueluis. Het is hieruit dus moeilijk af te leiden welke soort in het begin der vorige eeuw werd bedoeld met co(c)queluis. Dit woord wordt momenteel niet meer op Curaçao vernomen. Echter lezen we nog in Jansen's Nederlands-Papiaments woordenboek (I947, p. 95) kokkeluis = cocolishi, maar JANSEN ( 1945 , p. 40; I947, p. I56) geeft ook de moderne betekenis voor cocolishi: schelp.

Het woord coqueluis of kokkeluis is echter ook niet (meer) in gebruik in het Nederlands, mevr. dr. W. S. S. vAN DER FEEN-vaN Benthem Jutting noch de schrijver kennen enige schelpensoort die zo genoemd wordt of werd. (Wel kent het Nederlands de kokkel, dit is de hartschelp Cardium edule L.).

Het 'Papiamentse' co(c)queluis is verbasterd tot cocolishi, en kreeg tevens een uitbreiding van zijn betekenis, van een bepaalde schelpensoort tot schelpen in het algemeen. Ook BRENNEkER (I954, p. Io) bevestigt dat cocolishi afkomstig is van het oudnederlandse cocqueluis.

Het woord coqueluis duidt op een Franse herkomst: 'coqueluche' is een kap, en ook kinkhoest. 'Coqueluchon' is eveneens muts, ook een monnikskap (plant), en in de vorige eeuw tevens de naam van een bepaalde arkschelp, Cucullaea auriculifera, of oorkapschelp (KRAMERS, I859, p. 424; KRAMERS \& BONTE, I88I, p. 449).

Of de kinkhoest (in het Frans en Spaans 'coqueluche') nog iets met de schelpdieren te maken heeft, blijft de vraag. Het is bekend dat het slijm van naakte landslakken, dat zijn slakken zonder slakkenhuis, destijds als geneesmiddel tegen de kinkhoest werd aangewend, zogenaamde slakkenstroop (vAN BENTHEM JUTTING, I952, p. I28; DE WAAL, z.j., p. IOO). Vergelijk hiermee het Curaçaose gebruik van cocolishi (zie aldaar) tegen asthma.

Het 'kink' in kinkhoest en in kinkhoren is echter van verschillende betekenis: kinken $=$ zwaar ademen, en kink $=$ draai, cf. kink in de kabel (DE VRIES, I958, p. I27).

\section{Djacaráo [Fig. I2] Nerita peloronta,Linnaeus}

Deze naam is alleen op Bonaire bekend. Brenneker (I959, p. 4) vermeldt dat het een eetbare soort is, en hij deelde ons mede dat met deze naam Nerita peloronta bedoeld wordt. Frater ARNoLDO informeerde voor ons op Bonaire, maar aanvankelijk bleek niemand ooit van djacarao gehoord te hebben. Op school had hij meer succes; in een collectie schelpen wezen zijn leerlingen Nerita 
peloronta aan, soms ook Nerita versicolor Gmelin, een verwante soort. Maar deze Bonairiaanse jongens beweerden, in tegenstelling tot BRENNEKER, dat de schelpdieren niet gegeten worden.

De oorsprong van het woord djacarao is niet duidelijk, taalkundigen konden ons geen verklarende oplossing geven. Het $\mathrm{Pa}-$ piamentse 'djaca' (= rat), en de Portugese uitgang -rao kan een vergroting aanduiden, maar het is onwaarschijnlijk dat djacarao als zodanig moet worden uitgelegd. Het lijkt veiliger om aan te nemen dat dit woord van Indiaanse oorsprong is.

Volgens MADURo wordt dezelfde soort, Nerita peloronta, op Curaçao krekchi genoemd.

Hústu [Fig. 20] Crassostrea rhizophorae (Guilding)

Hustu of hoestoe is een verbastering van oester (zie aldaar). Beide namen, hustu en oester, worden door elkaar gebruikt op de ABCeilanden. (Zie ook cocolishi hustu).

Kakaláka di áwa [Fig. I5]

Zie cacalaca di awa.

\section{Karkó [Fig. 3]}

Zie carco.

Kincón [Fig. 3] Strombus gigas Linnaeus

Kincon of kinkon is een andere naam voor de carco (zie aldaar). Volgens BRENNEKER (I96I, p. 3I, no. II3) is dit woord een verbastering van het Nederlandse 'kinkhoorn', omdat de schelp vroeger als zodanig in gebruik was. Deze verklaring is voor ons niet geheel bevredigend, te meer omdat de naam kinkhoorn geen gebruik aanduidt (kink $=$ draai, dus letterlijk een gedraaide hoorn).

Het is wellicht mogelijk dat kincon een verbastering is van 'king conch', hetwelk de locale naam van Strombus gigas op de Bovenwinden is. (Het Spaans voor kinkhoorn is bocina.) Overigens wordt de naam kincon zeer weinig gebruikt op de Benedenwinden, iedereen spreekt van carco. 
VOLKSNAMEN VOOR WEEKDIEREN OP NED. ANTILLEN I69

Kíwa [Fig. 7] Cittarium pica (Linnaeus)

De kiwa is een algemeen voorkomende zeeschelp in West-Indië welke op rotskusten leeft. Het dier wordt gegeten (Coomans, I959, p. I4). Een moderne studie over dit weekdier werd geschreven door Helen A. Randall (I964).

Volgens mededeling van Antoine J. Maduro is het woord kiwa van Indiaanse oorsprong: in Venezuela heet het dier quigua, in Cuba sigua. Voor Io stuks werd in november I969 NAf. 2,betaald.

\section{Kokkeluis}

Zie onder co(c)queluis.

\section{Kokolí(e)sji(e)}

Zie onder cocolishi.

Koorkóor [Fig. 3] Strombus gigas Linnaeus

Bij Simons (I868, p. I5I) vinden we dit woord als inlandse benaming van Strombus gigas. Waarschijnlijk is hier bedoeld 'karko' (zie aldaar), dat door Simons verkeerd verstaan werd, of het is een drukfout (Coomans, I964, p. 205).

Simons (p. I52) vermeldt ook een vis met de naam 'koor-koor', volgens hem de inlandse benaming van Chaetodon fromitus. BRENNEKER (I947; I953, p. IOI), die veel volksnamen van Curaçaose vissen noemt, geeft de spelling 'corco(u)'. Volgens ZANEveld (I959, p. II, no. II9) is de 'corco, corcor of koorkoor' de vissoort Haemulon sciurus (Shaw), een knorbaars. Koorkoor moet zijn afgeleid van knorknor, hetgeen we reeds bij TEENSTRA (I836, p. 268) kunnen vinden in 'koor-koorbaars (Knorrebaars)'.

Krékchi, krewchi of kreuchi [Fig. I2] Nerita peloronta Linnaeus

Deze naam komt voor bij Maduro (I966, p. 39), die zegt dat het een soort zeeslakje is, en terecht meent dat het woord is afgeleid van het Nederlandse kreukel. In Nederland, inz. Zeeland, is kreukel of alikruik (zie aldaar) de naam voor Littorina littorea (L.). Het dier dat Antoine J. Maduro ter determinatie zond bleek een Nerita peloronta te zijn, zodat mag worden aangenomen 
dat op Curaçao met het woord krewchi inderdaad de op alikruiken gelijkende, op de rotskust voorkomende, zeeslakjes worden aangeduid. De krekchi's worden niet gegeten, de alikruiken wèl.

Mangrove oester

[Fig. 20]

Zie onder oester.

Oester

[Fig. 20]

Crassostrea rhizophorae (Guilding)

Uit de literatuur is bekend dat in de vorige eeuw locale oesters gegeten werden (PADDENBERG, I8I9, p. 44-45; Bosch, I829, p. I70; I836, p. 59 ; vaN DISSEL, I868, p. 443, 462), maar het gebruik werd allengs minder en is momenteel nihil (Coomans, I959, p. 2I). In ieder geval dankt dit weekdier aan het consumptiegebruik zijn volksnaam, letterlijk overgenomen van het Nederlands, maar dikwijls verbasterd tot hustu of hoestoe.

Crassostrea rhizophorae is de mangrove oester. Deze soort leeft vastgehecht aan de steltwortels van de mangrove Rhizophora mangle L., in het Papiament de manguel tan, die op alle drie Benedenwindse eilanden langs de oevers van binnenbaaien voorkomt.

Palúli [Fig. 2I] Brachidontes exustus (Linnaeus)

Paluli, paloeli of paloli, is de Papiamentse naam voor mossel. De locale mosselen worden niet meer gegeten op de Nederlandse Antillen, in de vorige eeuw echter wel en het is dus verklaarbaar dat de mossel een volksnaam heeft.

Drie mosselsoorten leven op de Benedenwinden (Coomans, I959, p. I5-I6, I7a). Behalve de reeds genoemde die algemeen voorkomt, vinden we Brachidontes citrinus (Röding) en B. recurvus (Rafinesque), beide zijn veel minder algemeen. De mosselsoorten van de Antillen zijn veel kleiner dan de eetbare Europese mossel, Mytilus edulis L.

Paluli is de oudste niet-Nederlandse schelpennaam ons bekend uit de Antilliaanse literatuur (Teenstra, I836, p. 289: "terwijl de weinige hier gevondene mosselen, Paloulie ... van weinig waarde zijn"). Ook bij Simons (I868, p. I50: "Paloeli, mosselen") komen we deze naam tegen, en nog later bij BoEke (I907, p. I43: "mosselen, paloelie"). Merkwaardig daarom is het dat BRENNE- 
VOLKSNAMEN VOOR WEEKDIEREN OP NED. ANTILLEN I7I

KER deze naam niet noemt in zijn publicaties, en hij deelde ons ook mee dit woord nooit te hebben vernomen, terwijl hij toch een kenner van Papiamentse vis- en schelpennamen bij uitstek is. Zou het woord paluli gaan verdwijnen uit het Papiamento? We vinden het nog wel genoemd bij JANSEN (I947, p. II3: "mossel = paluli").

De herkomst van het woord paluli is niet duidelijk; wellicht is het van Indiaanse oorsprong.

\section{Palúli di téra [Fig. II]}

Zie patoeti di vera.

\section{Patóeti di véra [Fig. II] ?Asaphis deflorara (Linnaeus)}

Deze naam wordt als volksnaam genoemd in Simons (I868, p. I50), maar zij bevat zonder twijfel twee fouten. Zoals wij (CooMANS, I964, p. I99-200) reeds hebben aangetoond zal de naam moeten luiden 'paloeli di tera'. Deze naam is heden niet meer bekend op Curaçao.

Het is niet geheel zeker of Asaphis deflorata met deze volksnaam wordt bedoeld, in ieder geval is het niet de soort die Simons opgeeft, Unio pictorum (L.), een Europese zoetwatermossel.

\section{Sepia}

[Fig. I7]

Ook aangeduid als zeepia, zie hiervoor onder Spaansche zeekat.

\section{Soldáchi}

Deze naam, afgeleid van soldaatje, wordt gegeven aan de heremietkreeften, dieren met een week achterlichaam waarvoor zij bescherming zoeken in een leeg slakkenhuis. In feite zijn het dus geen weekdieren en vallen derhalve buiten ons onderwerp. Maar een kreeft in een slakkenhuis zou een niet-bioloog in verwarring kunnen brengen. Zo geeft JANSEN (I947, p. I6I) in zijn Nederlands-Papiaments woordenboek als vertaling van slak: soldachi, echter noemt hij (p. 78) een heremiet 'krab' eveneens soldachi. Op de Nederlandse Antillen leven soldachis zowel op het land als in zee. 


\section{Spaansche zeekát [Fig. I7] Decapode inktvis}

Bij Paddenberg (I8r9, p. 45) lezen we: "de Spaansche zeekat of sepia zijn er ook in menigte; de laatste wordt door sommigen gegeten, hoe afschuwelijk dit slijmerig dier ook zijn moge". TEEnstra (1836, p. 288) heeft dit bijna letterlijk overgenomen: "Spaansche zeekatten of zeepia's (een negervoedsel, ofschoon een slijmerig en afschuwelijk dier zijnde)".

Uit het voorvoegsel 'Spaansche' leiden we af dat Spaansche zeekat een locale naam was, tegenwoordig spreekt men zonder meer van zeekat (zie aldaar). Omdat de schrijvers erop wijzen dat de Spaansche zeekat een Sepia is, wordt hiermee kennelijk een tien-armige inktvis (Decapoda) bedoeld, en niet de achtarmige Octopus. Of de naam sepia destijds ook in gebruik was op Curaçao, is uit de tekst bij Paddenberg en Teenstra niet met zekerheid te zeggen.

Tápa cónchi [Fig. 5\& I5] Acanthopleura granulata (Gmelin), Chitonen, hoedjesslakken, zeepokken (Balanus) en een vis (Batrachus)

Volgens diverse auteurs (Simons, I868, p. I50; BoEke, I907, p. I43) worden hieronder de chitons of keverslakken van de Benedenwinden begrepen. De eerstgenoemde soort, Acanthopleura granulata, is zeer algemeen en wordt gegeten door de locale bevolking (Coomans, I959, p. 30). Vooral voor deze soort zal de naam tapa conchi (het wordt ook als één woord geschreven) dus wel bedoeld zijn. De keverslakken leven en kruipen op de rotsen in de brandingszone.

In hetzelfde gebied komen ook bepaalde slakken voor met dezelfde levenswijze en een napvormige schelp. $\mathrm{Zij}$ behoren tot verschillende families waarvoor de Engelse taal het verzamelwoord 'limpets' kent, in het Nederlands hoedjesslakken genoemd. Volgens dr. I. J. Hermans worden deze 'limpets' ook met tapa conchi aangeduid, en de keverslakken onderscheidt men dan als cacalaca di awa (zie aldaar). Een nog grotere uitbreiding van de betekenis van tapa conchi vinden we in de beide woordenboeken van JANSEN (I945, p. I53; I947, p. 223). Hij spreekt van tapa concha, en geeft als vertaling zeepok(ken), en bovendien leert hij ons dat deze dieren op Aruba cleconchi worden genoemd. On- 
VOLKSNAMEN VOOR WEEKDIEREN OP NED. ANTILLEN I73

danks dat de zeepokken (Balanus) een schelp hebben, behoren zij in zoölogische zin niet tot de groep welke wij de schelp- of weekdieren (Mollusca) noemen. Maar om hun gelijkenis met de hoedjesslakken, terwijl ze in hetzelfde gebied voorkomen, vastgehecht op de rotsen in de branding, zal de locale bevolking er geen bezwaren in zien om de zeepokken eveneens tapa conchi te noemen.

METZELAAR (I9I9, p. I79) vermeldt tapa-conchie als naam van een vis (Batrachus), bij ZANEVELD (I959) komt deze naam niet voor.

\section{Zeekát}

[Fig. I8-I9]

Dit woord is onveranderd overgenomen uit het Nederlands, al ligt in het Papiamento de klemtoon op de laatste lettergreep. In het algemeen verstaat men onder een zeekat een inktvis, en in het bijzonder de achtarmige Octopus. Dit in tegenstelling tot het Nederlands, waar de zeekat een Sepia (tienarmige inktvis) is. Omdat inktvissen algemeen voorkomen rondom de $\mathrm{ABC}$-eilanden en door de vissers geregeld worden gevangen, zijn ze dus goed bekend. Bovendien worden inktvissen gegeten, en als aas gebruikt door de vissers; het is dus logisch dat de inktvis een Papiamentse naam gekregen heeft. Reeds in de vorige eeuw lezen we bij PADDENBerG (I8I9, p. 45) en Teenstra (I836, p. 288) dat Spaanse zeekatten of sepia's door de locale bevolking worden gegeten.

De Westindische inktvissen worden in twee groepen onderscheiden: de acht-armigen (Octopoda), dit zijn bodemdieren met acht even lange tentakels, en de tien-armigen (Decapoda) die een zwemmend leven leiden en waarvan het lichaam acht korte en twee lange tentakels heeft. In het Papiamento zijn beide groepen te herkennen, want men kent diverse soorten van zeekatten, die hierna besproken worden.

\section{Zeekát buladó(r) [Fig. I7] Sepioteuthis sepioidea Blainville}

Onder 'bulado' verstaat men een vlieger, en ook een vliegende vis. Een vliegende inktvis is derhalve een inktvis met een zwemmende levenswijze, dus een tienarmige, zoals ook frater ARNOLDO (I96I, p. 57, fig. 73) meedeelt, die de Nederlandse naam pijlinktvis noemt. Sepioteuthis sepioidea is algemeen rondom de eilanden, en zal dus wel speciaal bedoeld zijn als de zeekat bulado. 


\section{Zeekát corá}

[Fig. I8-I9]

Octopus soorten

Inktvissen bezitten de eigenschap om van kleur te kunnen veranderen, aan deze eigenschap is ongetwijfeld de naam cora (= rood) te danken. Biologisch is een rode inktvis dus geen aparte soort, slechts een inktvis in een bepaalde kleurtoestand. De schrijver heeft de bruinrode verkleuring bij de Curaçaose Octopus zelf waargenomen, en wij nemen aan dat de vissers naar dezelfde ervaring met een zeekat cora een Octopus bedoelen.

\section{Zeekát di piédra [Fig. I8-I9] Octopus soorten}

De Octopus woont in een hol of nest dat hij dikwijls zelf maakt van stenen. Het is derhalve duidelijk dat met zeekat di 'piedra' (= steen) de Octopus bedoeld wordt.

\section{Zeekát pía lárgu [Fig. I7] Decapode inktvis}

De zeekat 'met lange voeten' is een tienarmige inktvis, die acht korte en twee lange tentakels heeft. Verschillende soorten komen rondom de Benedenwinden voor (ADAM, I937).

\section{Zeekát tumadó}

Voor de betekenis van 'tumado' werden ons twee verklaringen gegeven:a) afgeleid van tumba (Spaans tumbar) = omvergooien; b) afgeleid van tuma (Spaans tomar) = nemen, grijpen. Wij geven de voorkeur aan de laatste verklaring, immers een inktvis gebruikt de tentakels met zuignappen om zijn prooi vast te grijpen, en wat kan er door een inktvis worden omgegooid? Bovendien is de naam 'tumado', en niet 'tumbado'. Omdat alle inktvissen hun prooi beetpakken is uit de naam zeekat tumado niet duidelijk welke soort inktvis bedoeld wordt.

\section{Zilverschelp [Fig. 4] Strombus costatus Gmelin}

Deze naam werd door BrennekeR (I953, p. 40, 97) gegeven aan de carco duru (zie aldaar). De naam is niet ingeburgerd. 
Spelingswijze en Afleiding van De Papiamentse Namen

Aangezien er geen definitieve spelling is van het Papiamento zijn er voor veel woorden diverse schrijfwijzen mogelijk, zoals: carco en karko, cocolishi of kokoli(e)sji(e) en kokelisje, hustu en hoestoe, paloelie en paluli, kalakoena of kalkoena en calacuna. Wel zijn er enkele, overigens nietbindende, spellingsregels.

De Nederlandse oe-klank wordt in het Papiaments als ' $u$ ' geschreven, behalve in woorden die niet of nauwelijks van het Nederlands verschillen, dus 'oester' blijft oester, en wordt geen 'uster'. Paluli, dat niet van Nederlandse herkomst is, heeft dus de voorkeur boven paloeli.

De klinker i wordt uitgesproken als ie, derhalve is paluli en kokolisji voldoende.

De Nederlandse $\mathrm{k}$ kan voor de klinkers a, o en $\mathrm{u}$ als een $\mathrm{c}$ geschreven worden, dus carco en cocolishi in plaats van karko en kokolishi. Dit is zelfs aan te bevelen als de woorden van een latijnse taal afkomstig zijn, zoals de beide voorbeelden carco (van caracol) en cocolishi (van coqueluis $=$ coqueluche). In de woorden die nog te weinig of in het geheel niet van het Nederlands verschillen blijft de $\mathrm{k}$ gehandhaafd, zoals in zeekat.

Bij sterk verbasterde woorden prefereren wij een Papiamentse (i.c. latijnse) schrijfwijze boven de Nederlandse, dus hustu i.p.v. hoestoe, cacalaca i.p.v. kakalaka.

Het Papiamento is een mengtaal met vooral Spaanse, en verder Portugese, Nederlandse, Engelse, Indiaanse en Afrikaanse invloeden. De door ons vermelde schelpennamen of delen van namen worden hieronder behandeld volgens de taal van oorsprong. Ten einde de uitspraak van de niet met het Papiaments vertrouwde lezer te vergemakkelijken, zijn klemtoontekens aangebracht.

I) ongewijzigd overgenomen uit het Nederlands :

$\begin{array}{ll}\text { alikruik } & \text { oester } \\ \text { ammonshoren } & \text { sepia } \\ \text { cocqueluis } & \text { zeekát }\end{array}$

2) verbasterd naar het Nederlands:
cacaláca (kakkerlak)
? kinkón (kinkhoorn)
clecónchi ( ? kleef-conchi) krékchi, kréwchi of kréuchi (kreukel) cocolíshi (cocqueluis, kokkeluis) hústu of hóestoe (oester) indján (indiaan) kalakóena (kalkoen)
rondó (rond) soldáchi (soldaatje)
3) overgenomen of verbasterd uit het Spaans (dan wel Portugees)
áwa (agua $=$ water) carcó $($ caracol $=$ slak $)$
buladó(r) (pez volador $=$ vliegende vis)
carné (carnero $=$ schaap)
cabrítu (cabra $=$ geit)
cónchi (concha $=$ schelp)
corá (Papiaments voor rood, Spaans is rojo; waarschijnlijk afgeleid van colorado $=$ gekleurd, rood)
dúru (duro $=$ hard)
lárgu (largo $=$ lang)
tápa (tapar $=$ bedekken $)$
téra (terra $=$ aarde $)$ 
4) verbasterd van het Engels: ? kincón (king conch)

5) van onbekende oorsprong. Wellicht van Indiaanse of van Afrikaanse herkomst, tenzij het een nieuwvorming is: djacaráo kíwa palúli

\section{LOCALE NAMEN OP DE BOVENWINDSE EILANDEN}

Op St. Maarten, Saba en St. Eustatius wordt het Engels als voertaal gebruikt. Derhalve zullen ook de volksnamen voor schelpen Engelse namen zijn. Tijdens ons verblijf op de Bovenwinden van 4 tot 22 juni 1959 hebben we getracht om locale namen van schelpen te vernemen, maar nagenoeg niemand kon ons iets meedelen. Slechts twee personen ontmoetten wij die ons een en ander wisten te vertellen. Op St. Maarten was het een jongen van Simpsonbay met de achternaam HALEY, destijds ongeveer I 5 jaar oud. Terwijl we schelpen verzamelden aan de Simpsonbaai, kwam de jonge Haley naar ons toe en bood schelpen te koop aan (o.a. Strombus gigas voor U.S.A. \$ I,50, en poppetjes gemaakt van schelpen, geverfd en gevernist voor Ant.fl. 4,一). Gezien het voor ons zinloos is om schelpen te kopen die gratis te verkrijgen zijn door zelf te verzamelen, boden wij hem geld aan als hij de namen van zijn schelpen kon zeggen. Hij kwam niet verder dan vier namen: chinese, king conch, queen conch en rose words.

Op Saba was de Administrateur, de heer E. C. LABEGA, zo vriendelijk om ons een gids mee te geven tijdens enkele van onze excursies. Het was een visser, James Carlton Riley, 30 jaar oud. Ook hij wist vier locale namen voor schelpen, alle eetbare soorten: conch, frenchman, long back en whelk. Volgens zijn zeggen zijn er meer schelpen die een Engelse naam hebben, maar hij kende ze niet. Wel vernamen wij nog van RILEY dat de weekdieren meestal gekookt gegeten worden, soms ook rauw (behalve de conch Strombus gigas). Men kookt ze met de schelp, behalve weer Strombus gigas die daarvoor te groot is zodat men het dier eerst uit de schelp haalt. Ook worden de dieren wel gestoofd, men eet ze tenslotte met peper en andere specerijen.

Literatuuronderzoek leverde ook niet veel volksnamen op. TeEnstra (I837, p. 259) noemt de long-back. In zijn beschrijving van St. Maarten vertelt hij (p. 26r) van een verzameltocht naar 
VOLKSNAMEN VOOR WEEKDIEREN OP NED. ANTILLEN I77

schelpen, die hij thuisgekomen in een doos met vakjes sorteerde. Maar helaas worden geen namen genoemd. Nogmaals komt TEenstra (p. 3I3) even terug op St. Maarten's mollusken: "niets overtreft de pracht en de verscheidenheid van de menigvuldige soorten schelpen van schelpdieren, die aan de kusten worden gevonden". KRUYTHOFF (I939, p. 6I-63) vermeldt van de Bovenwinden: oyster, whelk, rose conch en helmet conch; later (KRUYTHOFF, I964, p. 53) alleen de mangrove oyster. Collins (I956) noemt de conch van St. Maarten.

Wij beschikken over de aantekeningen betreffende Mollusken die werden gemaakt door H. E. van RiJgersma (I835-I877), gouvernementsarts te St. Maarten van 1863 tot I877. Maar deze amateur malacoloog gebruikt bijna uitsluitend de wetenschappelijke namen, van de locale schelpennamen vonden wij in zijn manuscript de queen conch en white long back.

Men zou kunnen verwachten dat de locale schelpennamen op de Bovenwinden dezelfde zijn als die van de Engels-sprekende landen waar dezelfde soorten voorkomen (i.c. de zuidoostelijke U.S.A. en Puerto Rico). Merkwaardigerwijs echter zijn alle namen verschillend (cf. Аввотт, I954; WARMKe \& Аввотт, I96r).

\section{LIJST VAN SCHELPENNAMEN VAN DE BOVENWINDEN}

De namen worden hieronder in alfabetische volgorde behandeld.

Chinese [Fig. Io] Tellina radiata Linnaeus

Dit is een tweekleppige schelp met fraaie kleuren, levend in zand, maar waarom deze soort chinese moet heten is niet duidelijk. De Amerikanen noemen haar 'sunrise tellin', het sunrise duidt op de stralentekening die op de schelp aanwezig is.

\section{Chipi-chipi}

Donax denticulatus Linnaeus

Een klein tweekleppig schelpdier dat - volgens mededeling van WAGENAAR HUMMELINCK - in het zand van Great Bay in grote getale voorkomt en op St. Maarten (evenals op verscheidene andere Bovenwindse Eilanden) soms wordt gegeten. Op dit eiland zouden zij bekend zijn als chipi-chipi, dezelfde naam waaronder zij ook in Venezuela bekend zijn. 
Conch [Fig. 3] Strombus gigas Linnaeus

In de Engels-sprekende landen is een 'conch' (cf. Spaans concha = schelp) een grote slak, en de diverse soorten worden dan door een 'voornaam' onderscheiden, zoals crown conch, queen conch, enz. Op de Nederlandse Bovenwindse Eilanden wordt conch zonder meer gebruikt voor de meest algemene soort, Strombus gigas, die ook king conch of rose conch wordt genoemd.

\section{Frenchman $\quad$ [Fig. 2] Purpura patula (Linnaeus)}

Deze purperslak is algemeen in West-Indië, ze leeft op de rotsen in de branding. In de U.S.A. wordt deze soort de 'wide mouthed purpura' genoemd, een naam die voor zichzelf spreekt omdat de schelp een grote mondopening heeft. Maar de naam frenchman kunnen wij niet verklaren.

\section{Helmet conch [Fig. I] Cassis tuberosa (Linnaeus)}

Deze naam lezen we bij Kruythoff (I939, p. 63): "Helmet Conchs may be obtained at low prices at Simpsons Bay", maar hij zegt niet welke soort hieronder verstaan wordt. Als zodanig duidt men aan Cassis tuberosa, die in de Verenigde Staten 'king helmet' genoemd wordt. Het is een van de grootste slakkesoorten van West-Indië, en derhalve opvallend. Op St. Maarten wordt ze ook 'queen conch' (zie aldaar) genoemd.

\section{King conch [Fig. 3] Strombus gigas Linnaeus}

Ook wel zonder meer 'conch' genoemd, en door KRUYTHOFF (1939, p. 63) als rose conch beschreven. De Amerikanen noemen deze soort queen conch, maar met die naam bedoelt men op onze Bovenwinden weer een andere soort, hetgeen dus nogal verwarrend is. De Amerikaanse literatuur kent geen king conch, wel een 'king's crown conch', Melongena corona (Gmelin), ook common crown conch geheten.

De king conch is een algemene soort op de Bovenwinden, ze wordt er gegeten, en op het Kerkhof te Little Bay op St. Maarten zagen wij de schelpen als grafversiering. Het gebruik van deze soort als hoorn bij de vissers van St. Maarten is beschreven en afgebeeld door Collins (I956), ze is aldaar vermeld als conch (cf. 
VOLKSNAMEN VOOR WEEKDIEREN OP NED. ANTILLEN I79

hetzelfde gebruik als hoorn op de Benedenwinden, onder carco).

In het manuscript van VAN RIJGERSMA, gedateerd I875, wordt de naam king conch niet genoemd, maar van Strombus gigas wordt door deze schrijver o.a. gezegd: "langwerpige ronde rooskleurige parels vindt men, maar zeer zeldzaam, in de schelp. Het dier wordt door de armen gegeten, en dient ook voor aas. De schelp bij de visschers om er op te blazen nadat men er de top heeft afgeslagen".

\section{Long back [Fig. I5] Acanthopleura granulata (Gmelin)}

Een zeer toepasselijke naam voor de keverslakken met hun langwerpige platte lichamen, die op de rotsen in de branding leven. Ook de naam long back wordt niet gebruikt in de U.S.A., men spreekt daar van 'chiton'.

We vinden deze naam reeds vermeld bij TeEnstra (i837, p. 259) in zijn hoofdstuk over St. Maarten. Hij beschrijft dit dier als "lelijke graauwe long-back's", zijnde "ongeveer een vinger lang en ongeveer twee vingeren breed". Zij hebben "geene voelhoorns of sprieten en geen pooten, maar houden zich, even als de hoornslak, aan rotsen vast. De rug van dit dier, die eene grauwe moskleur heeft, bestaat uit smalle ruwe ringschalen". Van de rots afgenomen "kan men er kop nog staart aan ontdekken. Hun vleesch wordt door sommigen voor een lekkernij gehouden". Deze uitvoerige beschrijving is zonder meer van toepassing op de soort Acanthopleura granulata.

Wij vonden op St. Maarten nog een tweede soort grote keverslak (Coomans, I963b, p. I75), Chiton squamosus Linnaeus, die volgens mijn zegsman aldaar ook een long back is.

In de nagelaten aantekeningen van VAN RIJGERSMA bevindt zich een lijst met Westindische schelpen. Daarin zijn nog meer Chiton soorten van St. Maarten genoemd, één soort is aangeduid als 'Chiton (white long back)'.

Mangrove oyster [Fig. 20] Crassostrea rhizophorae (Guilding)

Hiervan vertelt KRUYThofF (I964, p. 53) "Mangrove oysters (Ostrea rhizophora) can be collected by bagfulls in the Simpsonbay Lagoon". Dit is ongetwijfeld waar geweest in de tijd dat de lagune nog in verbinding stond met de open zee, maar sinds de opening is verzand zijn alle oesters gedood; in I959 vond de schrijver geen levende oesters aan de mangroves. 
Destijds werden mangrove oesters verkocht in Marigot, Frans St. Maarten, "a hat full for one franc (about 3 cents American money)" volgens KRUYTHOFF (I939, p. 77).

WARMKe \& ABbotT (I96I, p. I73) noemen deze soort Caribbean oyster.

\section{Oyster [Fig. 20] Crassostrea rhizophorae (Guilding)}

Ondanks dat er enkele soorten oesters op St. Maarten voorkomen (Coomans, I963b, p. I67) wordt er met oyster altijd de mangrove oyster bedoeld. Een van de binnenbaaien van St. Maarten is bekend als Oyster Pond. Wij troffen daar wel mangroves aan, maar de oesters ontbraken aan de bomen.

\section{Queen conch $\quad[$ Fig. I $] \quad$ Cassis tuberosa (Linnaeus)}

Met de naam queen conch duidt men in de U.S.A. de soort Strombus gigas aan, die echter op de Bovenwinden 'king conch' of 'rose conch' wordt genoemd. De queen conch van de Bovenwinden is Cassis tuberosa, een grote helmslak, die de Amerikanen 'king helmet' noemen, en op onze eilanden ook als helmet conch (zie aldaar) bekend is.

In het manuscript van van RIJGERSMa (de pagina met Cassis tuberosa is gedateerd 'St. Martin June I875') is o.a. te lezen: "Sometimes used to cut out cameos. Sold plentifully at the rate of 25 cents a pair as ornaments and is called the Queen Conch".

Rose conch [Fig. 3] Strombus gigas Linnaeus

Kruythoff (I939, p. 63) vermeldt dat de locale naam van de queen conch (in de Amerikaanse betekenis, dus Strombus gigas) 'rose conch' is, en goedkoop verhandeld wordt te Simpson Bay. Deze naam is zeer toepasselijk, omdat de porceleinachtige binnenzijde van het slakkenhuis prachtig rose gekleurd is.

\section{Rose words [Fig. 9] Tellina lineata Turton Strigilla carnaria (L.)}

De diverse rose gekleurde soorten van de familie der platschelpen (Tellinidae), behorende tot verschillende genera, werden door mijn zegsman op St. Maarten als 'rose words' aangeduid. De op- 


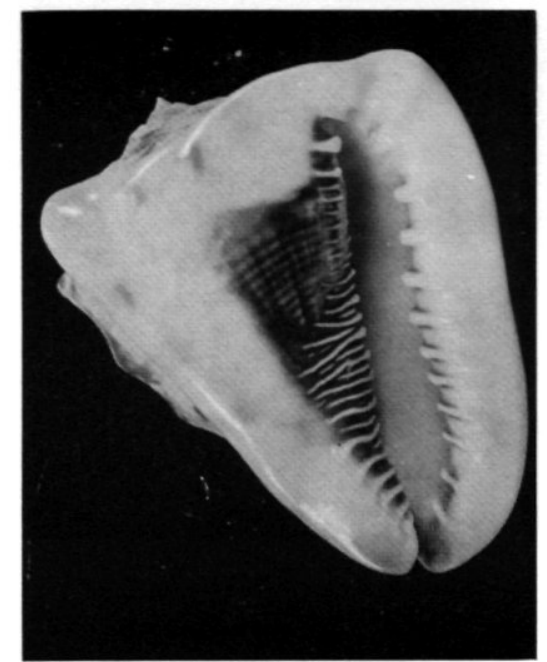

1

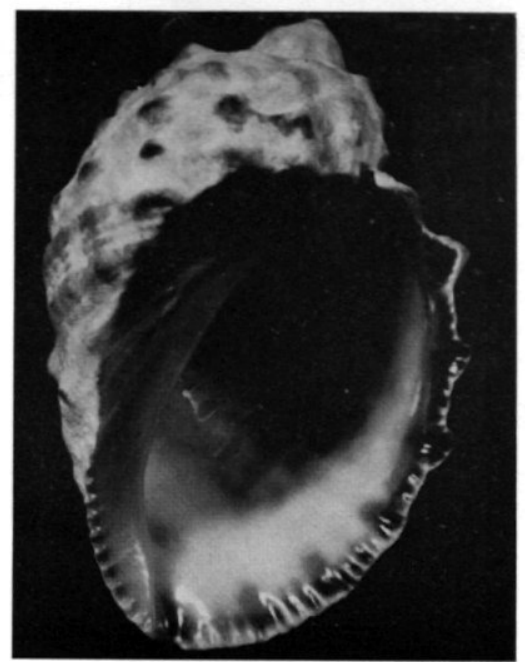

2

Fig. 1. Cassis tuberosa (L.), ?carcó indján, queen conch, helmet conch, hoogte $12 \mathrm{~cm}$

Fig. 2. Purpura patula (L.), frenchman, hoogte $48 \mathrm{~mm}$.

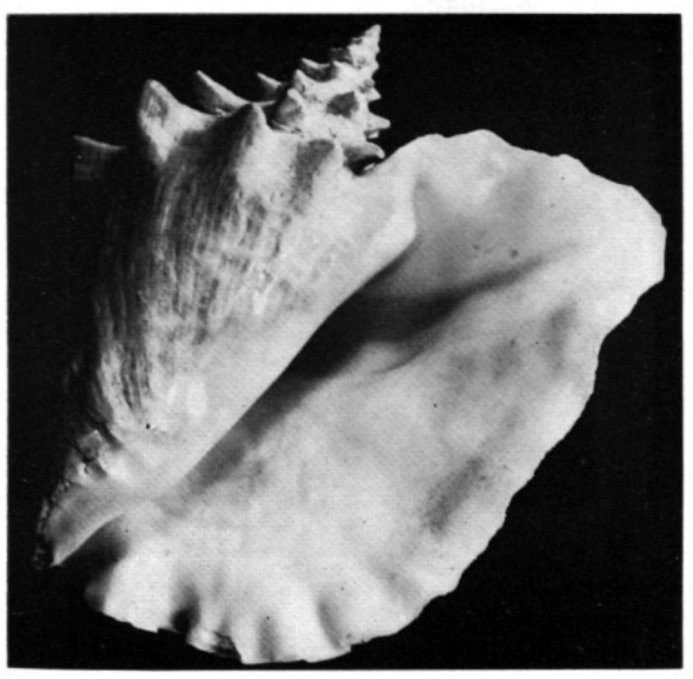

3

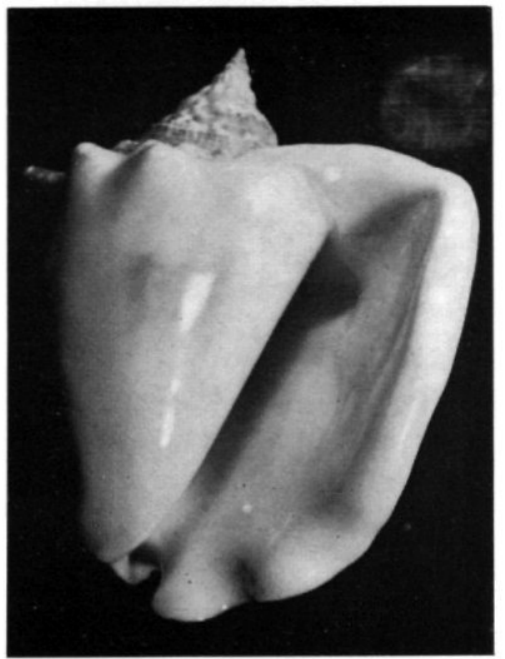

4

Fig. 3. Strombus gigas L., carcó, king conch, rose conch, hoogte $2 \mathrm{I} \mathrm{cm}$. Fig. 4. Strombus costatus $\mathrm{Gm}$., carcó dúru, hoogte $12 \mathrm{~cm}$. 


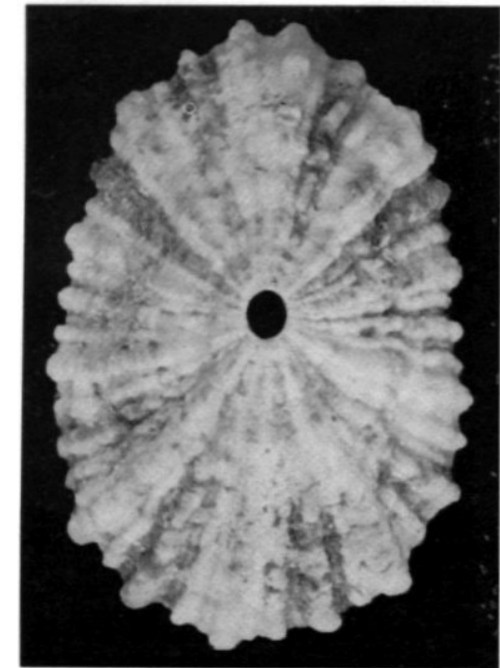

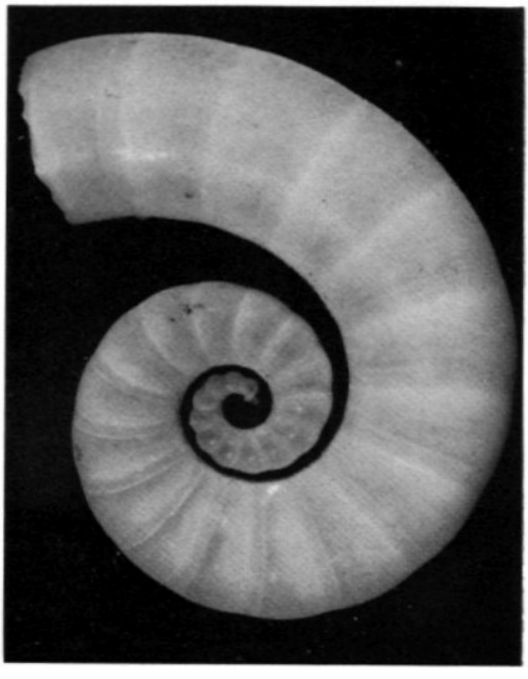

6

Fig. 5. Fissurella barbadensis (Gm.), clecónchi, tápa cónchi, lengte $29 \mathrm{~mm}$. Fig. 6. Spirula spirula (L.), ammonshoren, $20 \mathrm{~mm}$.

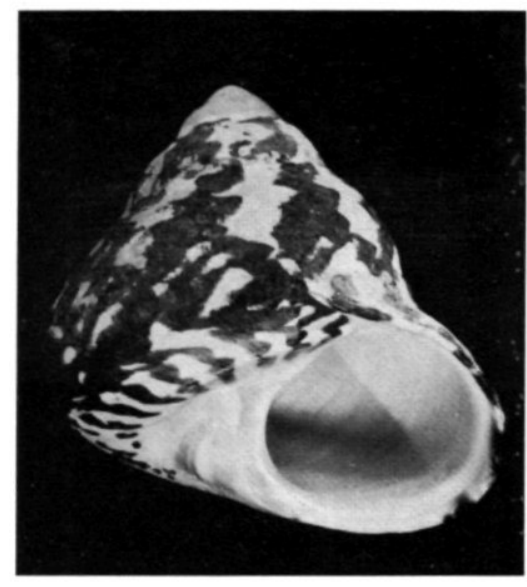

7

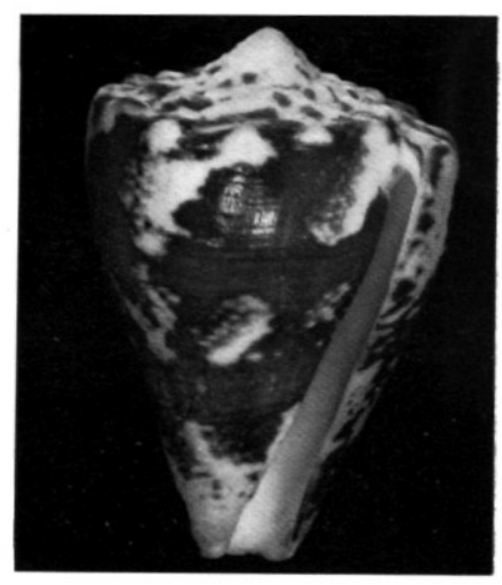

8

Fig. 7. Cittarium pica (L.), kíwa, whelk, hoogte $67 \mathrm{~mm}$.

Fig. 8. Conus regius $\mathrm{Gm}$., cocolíshi indján, hoogte $49 \mathrm{~mm}$. 


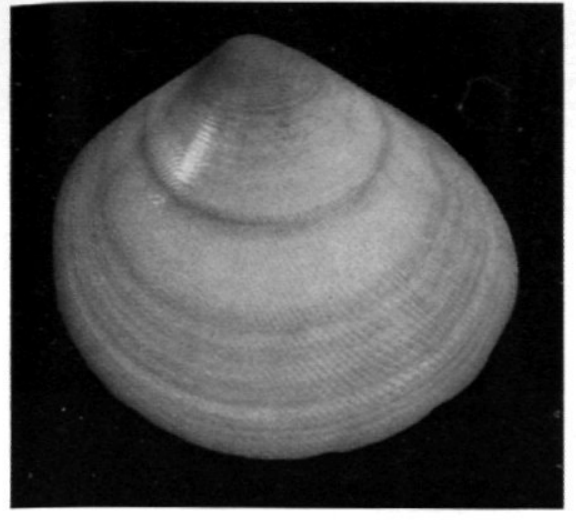

9

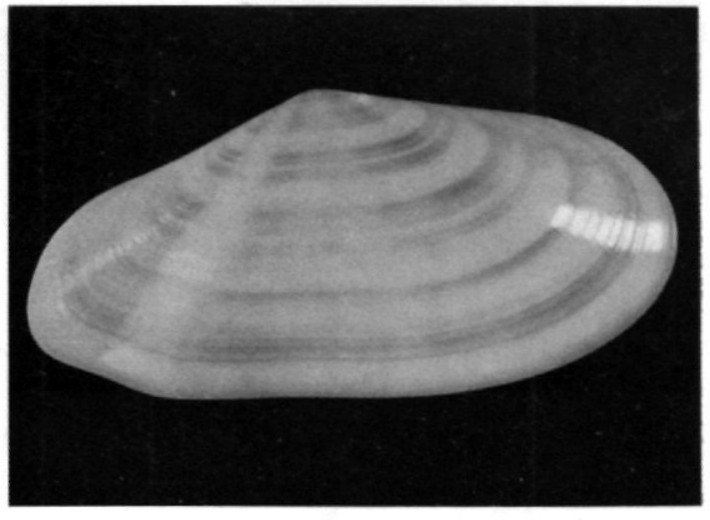

10

Fig. 9. Strigilla carnaria (L.), rose words, hoogte $16 \mathrm{~mm}$, breedte $18 \mathrm{~mm}$. Fig. Io. Tellina radiata L., chinese, hoogte $35 \mathrm{~mm}$, breedte $75 \mathrm{~mm}$.

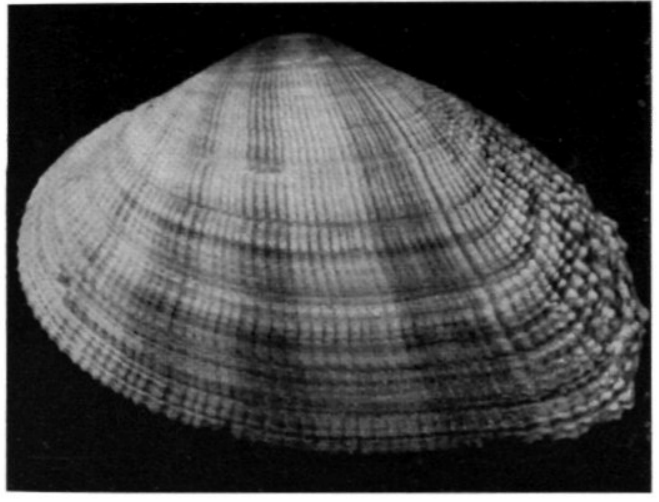

11

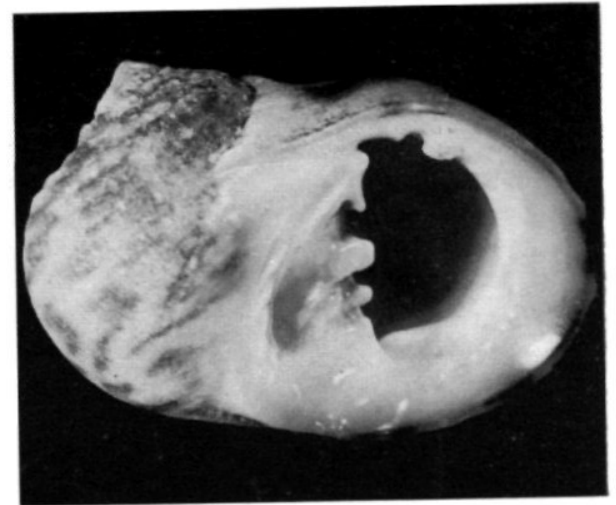

12

Fig. II. Asaphis deflorata (L.), ?palúli di téra, hoogte $31 \mathrm{~mm}$, breedte $4^{8} \mathrm{~mm}$.

Fig. I2. Nerita peloronta L., djacaráo, krékchi, hoogte $26 \mathrm{~mm}$, breedte $29 \mathrm{~mm}$. 


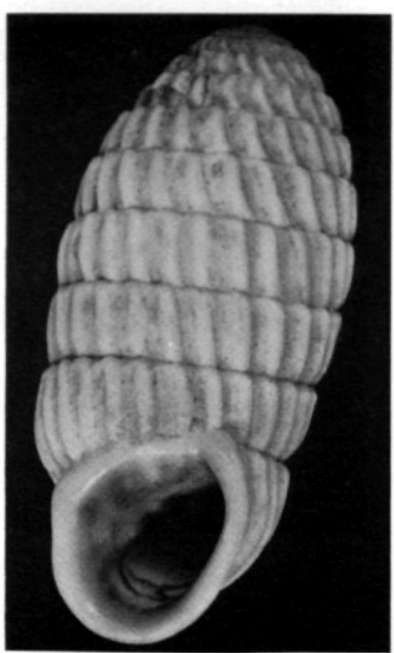

13

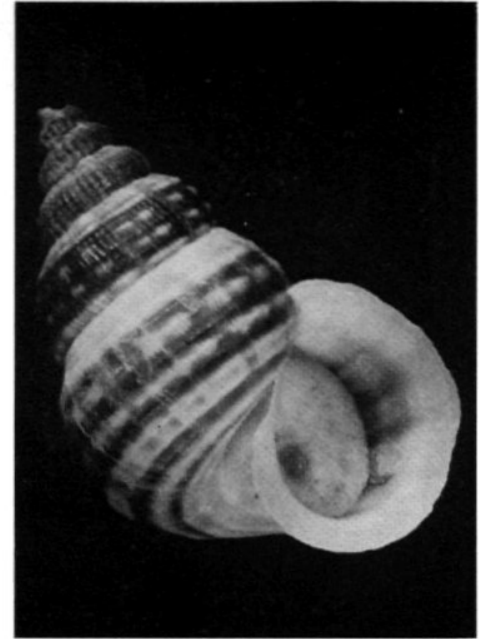

14

Fig. I3. Cerion uva (L.), cocolíshi di kalakóena, cocolíshi di carné, hoogte $23 \mathrm{~mm}$.

Fig. I4. Tudora megacheilos (Pot. \& Mich.), cocolíshi di cabrítu, hoogte I6 mm.

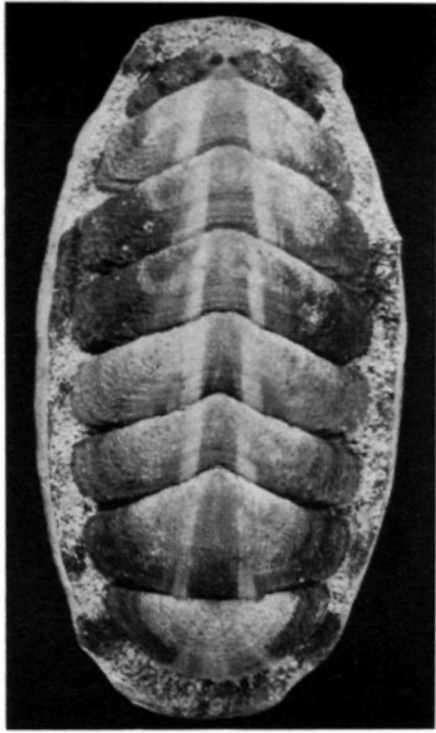

15

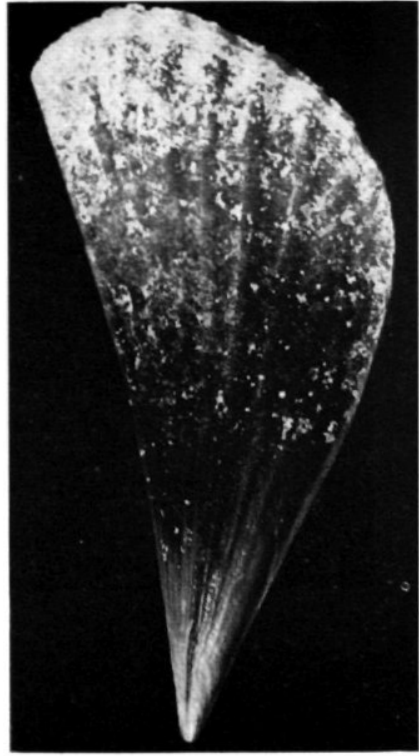

16

Fig. 15. Acanthopleura granulata (Gm.), tápa cónchi, cacaláca di áwa, long back, lengte $43 \mathrm{~mm}$.

Fig. I6. Pinna carnea Gm., cocolíshi hústu, hoogte $56 \mathrm{~mm}$, breedte $125 \mathrm{~mm}$. 


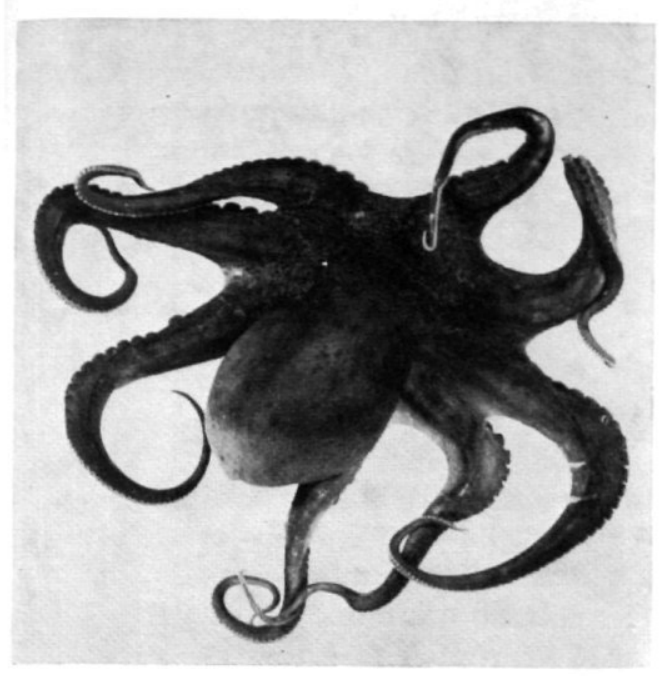

18

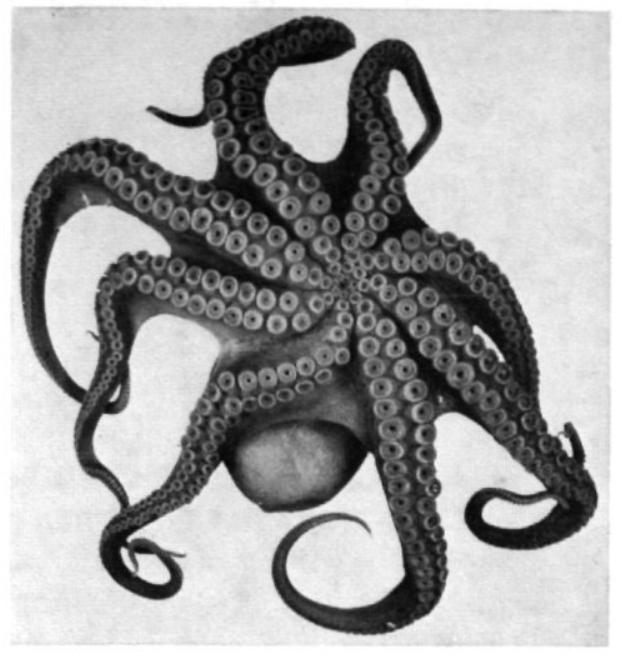

19

Fig. :8. Octopus vulgaris Lam., (bovenzijde), zeekát corá, zeekat di piédra omstreeks 2/5 ware grootte (geconserveerd dier).

Fig. 19. Octopus vulgaris (onderzijde van hetzelfde dier).

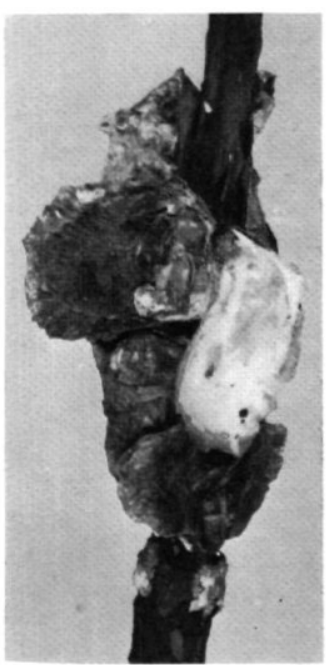

20

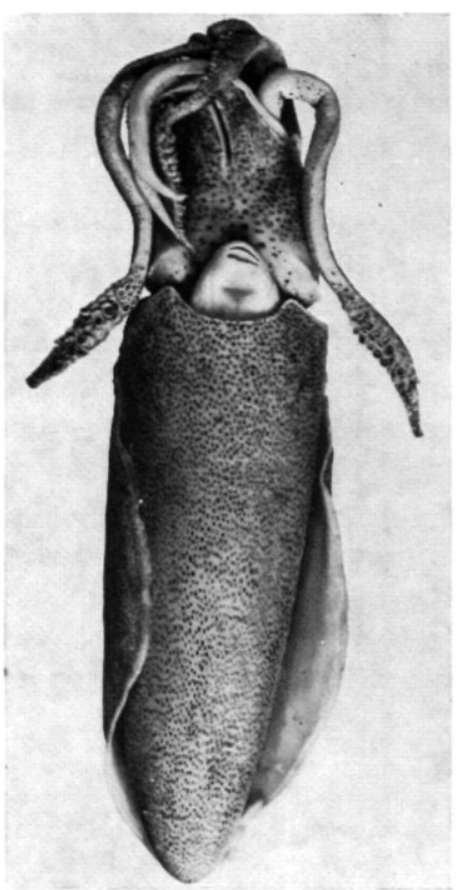

17

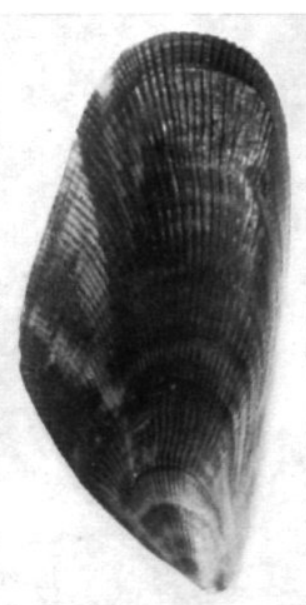

21

Fig. 2o. Crassostrea rhizophorae (Guild.), hústu, mangrove oyster, op stuk mangrovewortel van omstreeks $12 \mathrm{~cm}$ lengte.

Fig. 17. Sepioteuthis sepioidea Blainv., zeekát buladó, zeekát pía lárgu, I $4 \mathrm{~cm}$ lang (geconserveerd dier).

Fig. 21. Brachidontes exustus (L.), Falúli, hoogte ro $\mathrm{mm}$, breedte $22 \mathrm{~mm}$. 
VOLKSNAMEN VOOR WEEKDIEREN OP NED. ANTILLEN I8I

vallende rose kleur heeft er ongetwijfeld toe bijgedragen dat deze soorten van een locale naam werden voorzien, alhoewel er om die reden zo veel andere fraai gekleurde soorten een naam verdiend zouden hebben. In de U.S.A. noemt men ze 'tellin' en 'strigilla', dus een nagenoeg letterlijke overname van de Latijnse namen.

\section{Whelk [Fig. 7] Cittarium pica (Linnaeus)}

In de diverse Engels-sprekende landen verstaat men onder 'whelk' verschillende soorten:

Engeland: Buccinum undatum Linné, die in Nederland wulk heet. U.S.A.: Busycon soorten, die alleen aan de oostkust van de Verenigde Staten worden aangetroffen; Buccinum undatum noemt men hier 'common northern Buccinum'.

Bovenwinden: Cittarium pica, die in de U.S.A. als 'West Indian top-shell' wordt aangeduid.

Deze algemene soort dient op de Bovenwinden behalve als voedsel (KRUYTHOFF, I939, p. 62) ook als aas. In het laatste geval wordt de schelp stukgeslagen om het weekdierlichaam te verkrijgen.

\section{SYSTEMATISCH OVERZICHT VAN DE BEHANDELDE SOORTEN}

Zoals reeds gezegd komen er honderden soorten schelpdieren voor op en rondom de Nederlandse Antillen, maar slechts een gering aantal heeft een locale naam gekregen. Echter onder de soorten met een volksnaam treffen we vertegenwoordigers aan van bijna alle klassen der Weekdieren. De volgende lijst geeft een overzicht van de Mollusca volgens de zoölogische systematiek, waarin de hiervoor besproken weekdieren zijn ondergebracht.

De locale namen die momenteel niet meer gebruikt worden, zijn tussen haakjes geplaatst. Sommige namen zijn beperkt tot een bepaald eiland; deze zijn met de naam van het eiland genoemd. Een vraagteken voor de volksnaam betekent dat niet zeker is of deze soort aan de bepaalde naam beantwoordt. 


\begin{tabular}{|c|c|c|}
\hline & $\begin{array}{l}\text { BENEDENWINDEN } \\
\text { Curaçao, } \\
\text { Aruba, } \\
\text { Bonaire }\end{array}$ & $\begin{array}{l}\text { Bovenwinden } \\
\text { St. Maarten, } \\
\text { Saba, } \\
\text { St. Eustatius }\end{array}$ \\
\hline MoLlusca (Weekdieren) & cocolíshi & \\
\hline Klasse Gastropoda (Slakken) & cocolíshi & \\
\hline Zeeslakken & soldáchi & \\
\hline $\begin{array}{l}\text { families Fissurellidae \& Acmaei- } \\
\text { dae }\end{array}$ & $\begin{array}{l}\text { tápa cónchi } \\
\text { clecónchi (Ar.) }\end{array}$ & \\
\hline fam. Trochidae & & \\
\hline Cittarium pica (L.) & $\begin{array}{l}\text { kíwa } \\
\text { (alikruik) (Cur.) } \\
\text { ? (coqueluis) (Cur.) }\end{array}$ & whelk \\
\hline fam. Neritidae & & \\
\hline Nerita peloronta $\mathrm{L}$. & $\begin{array}{l}\text { djacaráo (Bon.) } \\
\text { krékchi, kréwchi, } \\
\text { kréuchi (Cur.) }\end{array}$ & \\
\hline fam. Strombidae & & \\
\hline Strombus gigas $\mathrm{L}$. & $\begin{array}{l}\text { carcó } \\
\text { (kincón) } \\
\text { (koorkóor) }\end{array}$ & $\begin{array}{l}\text { conch } \\
\text { king conch } \\
\text { rose conch }\end{array}$ \\
\hline Strombus costatus Gmel. & $\begin{array}{l}\text { carcó dúru } \\
\text { (zilverschelp) }\end{array}$ & \\
\hline fam. Cassidae & & \\
\hline Cassis tuberosa (L.) & ? carcó indján & $\begin{array}{l}\text { helmet conch } \\
\text { queen conch }\end{array}$ \\
\hline fam. Muricidae & & \\
\hline Purpura patula (L.) & & $\begin{array}{l}\text { frenchman } \\
\text { (Saba) }\end{array}$ \\
\hline fam. Melongenidae & & \\
\hline Melongena melongena (L.) & ? carcó indján & \\
\hline $\begin{array}{l}\text { fam. Conidae } \\
\text { Conus spec. }\end{array}$ & cocolíshi indián & \\
\hline Landslakken & & \\
\hline fam. Chondropomidae & & \\
\hline $\begin{array}{l}\text { Tudora megacheilos (Pot. \& } \\
\text { Mich.) }\end{array}$ & $\begin{array}{l}\text { cocolíshi di cabrítu } \\
\text { (Cur.) }\end{array}$ & \\
\hline fam. Cerionidae & & \\
\hline Cerion uva (L.) & $\begin{array}{l}\text { cocolíshi di } \\
\text { kalakóena (Cur.) } \\
\text { cocolishi di carné }\end{array}$ & \\
\hline $\begin{array}{l}\text { Klasse Pelecypoda (Tweekleppi- } \\
\text { gen) } \\
\text { fam. Mytilidae }\end{array}$ & & \\
\hline Brachidontes exustus (L.) & $\begin{array}{l}\text { palúli } \\
\text { ? (cocqueluis) }\end{array}$ & \\
\hline $\begin{array}{l}\text { fam. Pinnidae } \\
\quad \text { Pinna carnea Gmel. }\end{array}$ & cocolíshi hústu & \\
\hline
\end{tabular}


VOLKSNAMEN VOOR WEEKDIEREN OP NED. ANTILLEN I8 3

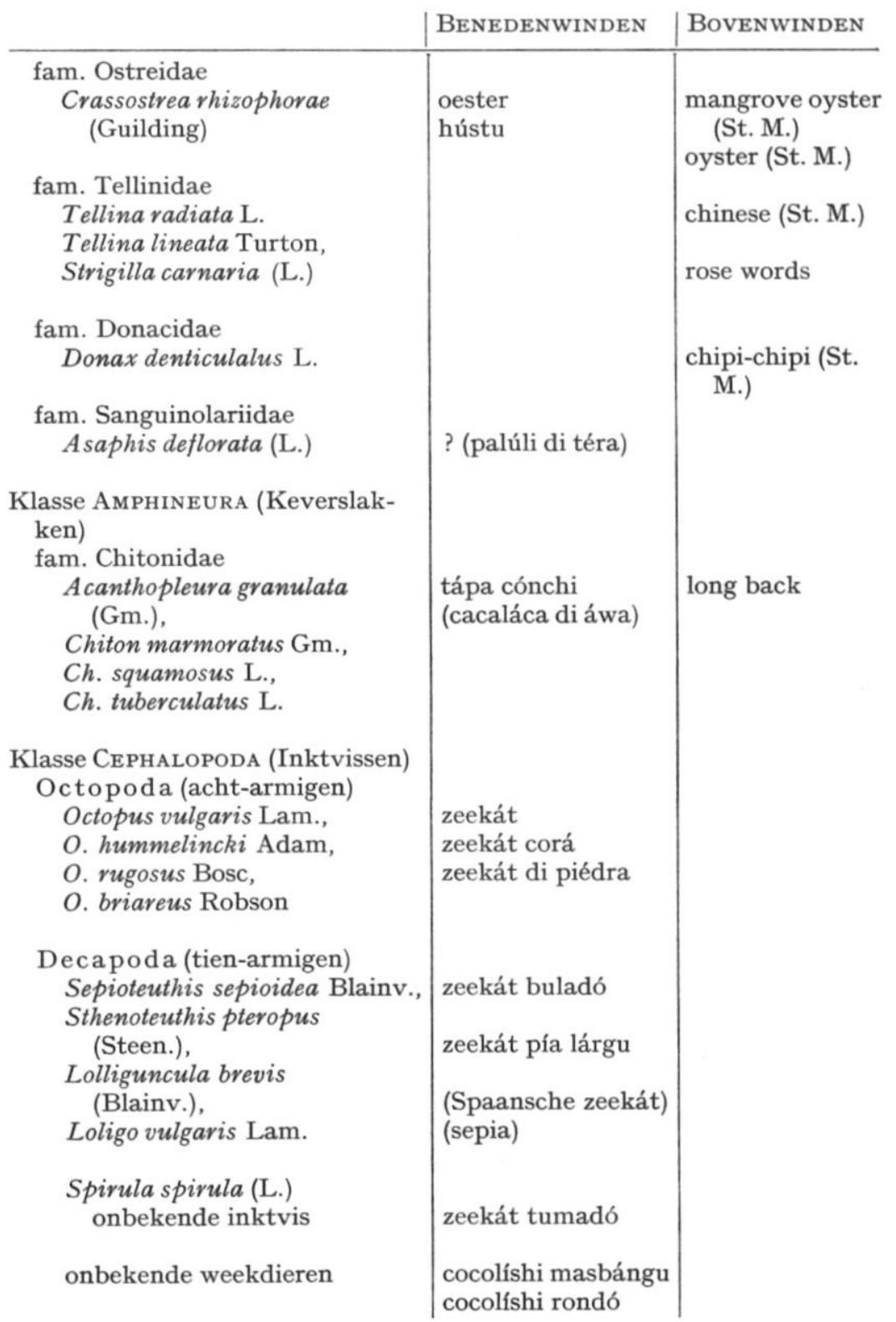




\section{LITERATUUR}

Aввотt, R. T., 1954. American seashells. Princeton.

Adam, W., 1937. Céphalopodes des îles Bonaire et Curaçao. Capita Zoologica 8 , pt. 3, p. I-29.

ANonIEM, 1875. Zie: Nederlandsch-Papiamentsch-Spaansch woordenboekje.

ANONIEM, 196r. Conch diet bolster body's defenses against polio. Medical world news, ${ }_{5}$ Sept. I96I, p. 7 .

ARnoldo, Fr. M., I96r. Buniteza den secura. Curaçao.

ArNoldo, Fr. M., 1954. Zakflora. Wat in het wild groeit en bloeit op Curaçao, Aruba en Bonaire. Curaçao. - I964: 2de herziene druk.

BAKer, H. B., 1924. Land and freshwater Molluscs of the Dutch Leeward Islands. Occ. Pap. Mus. Zool. Michigan ${ }^{52}$.

Benthem Jutting, W. S. S. van, 1925. On a collection of non-marine Mollusca from Curaçao. Bijdr. Dierk. 24, p. 25-32.

Benthem Jutting, W. S. S. van, I927. Marine Molluscs of the island of Curaçao. Bijdr. Dierk. 25, p. I-36.

Benthem Jutting, W. S. S. van, 1952. Weekdieren $2 e$ deel. Wat leeft en groeit 36. Utrecht.

Воеке, J., I907. Rapport betreffende een voorlopig onderzoek naar den toestand van de visscherij en de industrie van zeeproducten in de kolonie Curaçao, vol. I. 's-Gravenhage.

Bosch, G. B., I829, I836. Reizen in West-Indië, en door een gedeelte van Zuid-en Noord-Amerika. 2 dln. Utrecht.

[BRENNEKer, P.] I946. Frans van Venlo. Vis met de vissen. z. pl.

[Brenneker, P.] 1947. Paul van Venlo. Vissen van Curaçao. z. pl.

[BREnNeker, P.] I950. Paul van Venlo. Met de camera op de zeebodem van Curaçao. z. pl.

[BRenneker, P.] I953. Paul van Venlo. Vis met de vissen. Boeki chiki 9. Curaçao.

[Brenneker, P.] 1954. Paul van Venlo. Papiamentse visnamen afgeleid van het Nederlands. Boeki chiki 13. Curaçao.

Brenneker, P., 1959. In: Amigoe di Curaçao. 4 juli 1959, p. 4.

Brenneker, P., I961. Curaf̧aoensia. Folkloristische aantekeningen over Curaçao door pater -. Curaçao.

Collins, H. H., 1956. Birds and fish of the Netherlands Antilles. Bronxville.

Coomans, H. E., I958. A survey of the littoral Gastropoda of the Netherlands Antilles and other Caribbean islands. Stud. Fauna Curaf̧ao 8 , p. $42-$ III.

Coomans, H. E., 1959. Rapport betreffende het economisch gebruik van Weekdieren van de Nederlandse Antillen. Curaçao.

Coomans, H. E., I962. Voordelige effecten door het eten van slakken. Corr. blad Ned. Malacol. Veren. IOo, p. 1027-1028.

Coomans, H. E., I963a. The genus Conus in the southern Caribbean. Annual Rep. I963 Amer. Malacol. Un., p. 9-ro.

Coomans, H. E., 1963b. The marine Mollusca of Sint Martin, Lesser Antilles, especially from the French part. J. Conchyl. I03, p. Ir3I 86 .

Coomans, H. E., 1964. De eerste schelpenfauna van Curaçao, in Simon's beschrijving van dit eiland, 1868. Nwe West-Ind. Gids 43, p. 195210. 
Coomans, H. E., 1965. Shells and shell objects from an Indian site on Magueyes island, Puerto Rico. Carib. J. Sci. 5, p. 15-23.

Coomans, H. E., 1967. The non-marine Mollusca of St. Martin (Lesser Antilles). Stud. Fauna Curaçao 24, p. II8-145.

Dissel, S. VAN, I868. Eenige opmerkingen omtrent den stoffelijken toestand van het eiland Curaçao. Bijdr. Taal-Land-en Volkenk. Ned. Ind. (3) 3, p. 436-469.

Hakkenberg van GaAsbeek, H. C. M., 1955. Caraĩbisch steekspel. Assen. HeEkeren, H. R. van, 1963. Studies on the archaeology of the Netherlands Antilles: III. Prehistorical research on the islands of Curaçao, Aruba and Bonaire in 1960. Nwe West-Ind. Gids 43, p. I-24.

Husson, A. M., 1960. De zoogdieren van de Nederlandse Antillen. Curaçao. Jansen, G. P., 1945. Diccionario Papiamentu Holandes. Curaçao.

Jansen, G. P., 1947. Nederlands Papiaments handwoordenboek. Curaçao.

JonG, K. M. DE \& KRISTENSEN, I., I965. Gegevens over mariene Gastropoden van Curaçao. Corr. blad Ned. Malacol. Veren. Suppl. 1965.

Kramers, J., I859. Nouveau dictionnaire Français-Hollandais.

Kramers, J. \& Bonte, H. W. F., I88I. Nouveau dictionnaive FrançaisNéerlandais, 2de édit.

Kristensen, I., I963. Levende schelpen. De Passaat 20, no. 2, p. 2-5.

KruYthoff, S. J., 1939. The Netherlands Windward Islands and a few interesting items on French St. Martin. 2nd ed. Antigua.

KRUYThoFf, S. J., 1964. The Netherlands Windward Islands. 3rd ed. Aruba.

Maduro, A. J., I966. Procedencia di palabran papiamentu $i$ otro anotacionnan. Curaçao.

MetzelaAr, J., I9I9. Report on the fishes, collected by Dr. J. Boeke, in the Dutch West Indies, I904-I905, with comparative notes on marine fishes of tropical West Africa. Den Haag.

Nederlandsch-Papiamentsch-Spaansch woordenboekje. I875. Curaçao.

[PadDenberg, G. G. VAn,] I8I9. Beschrijving van het eiland Curaçao en onderhoorige eilanden. Uit onderscheidene stukken, bijdragen, en opmerkingen opgemaakt door een bewoner van dat eiland. Haarlem.

Randall, Helen A., 1964. A study of the growth and other aspects of the biology of the West Indian topshell, Cittarium pica (Linnaeus). Bull. Mar. Sci. Gulf Carib. 14, p. 424-443.

Randall, J. E., I964. Contributions to the biology of the queen conch, Strombus gigas. Bull. Mar. Sci. Gulf Carib. I4, p. 246-295.

Schepman, M. M., I9I5. Mollusca. In: Encyclopaedie van Nederlandsch West-Indie, 1914-1917. 's-Gravenhage, p. 477-482.

Simons, G. J., I868. Beschrijving van het eiland Curaçou uit verschillende bronnen bijeenverzameld. Oosterwolde.

Teenstra, M. D., I836-1837. De Nederlandsche West-Indische eilanden in derzelver tegenwoordigen toestand. 2 dln. Amsterdam.

Venlo, Frans van; Paul van. Zie: Brenneker, P.

Vernhout, J. H., I9I4. The land- and freshwater-Molluscs of the Dutch West-Indian islands. Notes Leyden Museum 36, p. I77-189.

Voous, K. H., 1955. De vogels van de Nederlandse Antillen. Curaçao.

VRIES, J. DE, 1958. Etymologisch woordenboek. Utrecht.

WAAL, M. DE, z.j. Dieren in de volksgeneeskunst. Antwerpen.

WagenaAr Hummelinck, P., I940. A survey of the mammals, lizards and mollusks. Stud. Fauna Curaçao I, no. 2, p. 59-108. 
I86 VOLKSNAMEN VOOR WEEKDIEREN OP NED. ANTILLEN

WagenaAr Hummelinck, P., I959. Indiaanse skeletvondsten op Aruba en Curaçao. West-Ind. Gids 39, p. 77-94.

WagenaAR Hummelinck, P. \& Roos, P. J., 1969. Een natuurwetenschappelijk onderzoek gericht op het behoud van het Lac op Bonaire. Nwe West-Ind. Gids 47, p. I-28.

Warmke, G. L. \& Аввотt, R. T., 196r. Caribbean seashells. Narberth. ZANEVELD, J. S., 1959. Index to the vernacular names of the fishes of the Netherlands Antilles. Trinidad.

\section{SUMMARY}

\section{VERNACULAR NAMES OF MOLLUSCS IN THE NETHERLANDS ANTILLES}

Many hundreds of species of shells are found on and around the six islands of the Netherlands Antilles. However, only a small number of these have received local names. Three languages are spoken on the islands: Dutch, Papiamento and English. - Papiamento is used in Curaçao, Aruba and Bonaire. It is a creole language with Spanish, Portuguese, Dutch, English, Indian and African elements. The molluscan names in Papiamento, whose origin is explained in the text, clearly show their mixed linguistic character. - On the Netherlands Antilles' Windward Islands, St. Martin, Saba and St. Eustatius, the English language is used. However, the local names for shells are different from those used for identical species in the U.S.A. and Puerto Rico.

Two alphabetical lists are given of local molluscan names in use now or no longer in use. In another list the species are placed in their proper systematical order. 